\title{
Fe Authority and Subject (in WAE the Archaeological Discourse in Austria and Germany)
}

Raimund Karl, Bangor, Gwynedd, UK

E-mail: r.karl@bangor.ac.uk

\begin{abstract}
The primary task of archaeological heritage management is to represent the public interest in archaeology. How this is constituted and determined has changed significantly over the past 200 years. As this paper demonstrates, a modern, egalitarian, democratic approach has yet to be established within Austrian and German archaeological heritage management: the relationship between heritage management bureaucracy and the civic subject is anachronistic, stuck in a pre-1848 Revolution mindset. Due to the lack of a public discourse and the nature of scholarly engagement with archaeological heritage management, the power of (state) archaeologists is not imaginary, but very real.
\end{abstract}

Résumé: La tâche primordiale de la gestion du patrimoine archéologique est de représenter l'intérêt public pour l'archéologie. La manière dont ceci est constitué et déterminé a fait l'objet de changements significatifs au cours des 200 dernières années. Ainsi que cet article le démontre, une approche moderne, égalitaire et démocratique doit encore être établie au sein de la gestion du patrimoine archéologique autrichien et allemand: la relation entre la bureaucratie de la gestion du patrimoine et le sujet civique est anachronique, bloquée dans un état d'esprit datant d'avant la révolution de 1848. En raison de l'absence d'un discours public et de la nature de l'implication académique en faveur de la gestion du patrimoine archéologique, le pouvoir des archéologues (de l'état) n'est pas imaginaire, mais très réel.

Resumen: La tarea principal de la administración del patrimonio arqueológico es representar el interés público en la arqueología. Cómo se constituye y determina esto ha cambiado significativamente en los últimos 200 años. Como lo demuestra este artículo, aún no se ha establecido un enfoque moderno, igualitario y democrático dentro de la administración del patrimonio arqueológico austríaco y alemán: la relación entre la burocracia administrativa del patrimonio y el tema cívico es anacrónica, atrapada en 
una mentalidad anterior a la revolución de 1848. Debido a la falta de un discurso público y la naturaleza del compromiso académico con la administración del patrimonio arqueológico, el poder de los arqueólogos (estatales) no es imaginario, sino muy real.

\section{KEY WORDS}

\section{Law, Policy, Practice}

It should not come as a surprise that, as archaeologists, we have an interest in the preservation of sources used to study the past: after all, they are essential to the research we do. While our motives may be noble-we may well want to serve the common good by preserving, studying and interpreting archaeology 'on behalf of and for the benefit of present and future generations' (ICOMOS 1990, 1)—strictly speaking, when arguing for the preservation (and study) of the archaeology, we act—at least partly-out of self-interest.

As a consequence, the power relationships between professional archaeologists and other stakeholders with justified, legal or other, interests in archaeology are particularly important in discourses about the public interest in archaeology (Karl 2016; cf. Art. 2 ICOMOS 1990; Art. 4 c and 5 a CoE 2005a, b, 7). After all, the primary task of archaeological heritage management is to balance, through public administration, private interests of any individual stakeholders with competing public interests which may affect archaeology. ${ }^{1}$ How public interest is determined, and who gets to determine it, and how it compares to other justified interests, is thus essential for whether archaeological structures and objects will be preserved in situ or by record, consequently studied in accordance with our self-interest, or left to whatever fate competing (other) private or public interests may hold for it.

\section{The Public Interest}

How public interest in archaeology should be determined, and by who, has changed significantly since archaeology emerged as an academic discipline, and archaeological heritage management became a function of public administration, in the 19th century. Within authoritarian societies during this early period, it was still deemed self-evident that it was to be determined top-down, by the ruling elite. This was justified by the belief that the ruling elite was composed of 'the best' members of society (Bloch 1961; Elias 1997). Whether they had been put in their place of authority 
by divine grace, as in the case of the Emperor, or due to noble birth or other suitable qualities (e.g. being 'learned' in the relevant subject matter) by the Emperor, they were deemed to have not just the right, but indeed the duty, to autocratically decide what was in the public interest (see Watzlawick 2001: 101-5). Everyone else under this ruling elite, that is, the subjects of the respective Emperor, had to listen and obey. This model of social organisation, characteristic for absolute monarchies and dictatorships, was dominant in Europe until the 20th century, and only then started slowly to decline. In Austria and Germany, it remained dominant, with some minor interruptions in the late nineteenth and early 20th century, until 1945.

However, with the rise of modern democracies, the determination of public interests significantly changed. Under this much more liberal-egalitarian model of organising societies, power is imagined to emanate from 'the people', with public interest to be determined bottom-up: the role of the state, and its officials, is only to balance the diverse interests of it citizens, rather than dictate to its citizens what is in their best interest (Habermas 1992). Based on the ideals of the Enlightenment (e.g. Kant 1784, 481), its 'responsible citizens' are supposed to decide for themselves what is in their, and by extension the public, interest. Ideally, the discourse by which this democratic public interest is determined should be one where each participant has equal power to contribute effectively his interests. The state's officials, on the other hand, must not restrict nor interfere with this discourse and implement its outcomes disinterestedly without fail, even if it is the opposite of what they themselves believe to be best for everyone (Habermas 1992, 249). This constitutes a complete role reversal: rather than having (and being) the authority entitled to determine what is best for everyone, public servants have to implement the collective decisions of the citizens. This role to place citizens at the heart of decisions is embedded in Austria and Germany's Constitutions, as in Article 1 of the Austrian Bundes-Verfassungsgesetz, first passed in 1923, and Article 20 of the German Grundgesetz, passed after the end of World War 2.

To determine whether archaeological heritage management in Austria and Germany corresponds more closely with the former or the latter model of social organisation, examining how (public) discourses regarding archaeology are ordered is particularly significant. After all, the order of the discourse determines who can contribute and who is excluded from, and what can and cannot be said in it (Foucault 2000, 10-30). If discourses are ordered in a manner excluding segments of society from participation, this is in keeping with the former, authoritarian-hierarchical system of social organisation. This indicates that the elite controlling such a discourse has immense power, even if it itself believes it is powerless. Furthermore, if that elite has been entrusted with (legal) authority by the state to act on behalf 
of and in the best interest of 'the public', with the potential of using given authority to advance its own at the expense of other individual and collective interests, this can lead to abuses of power. The risk for the latter occurring is especially high if members of this elite assume they know and thus believe they are entitled to decide on behalf of all others, what is best for them, even against their wishes (Watzlawick 2001). If such an elite does (ab)use the authority it has been entrusted with for its own utility, it does not act in the public interest, but is damaging it and the very fabric of the societies we live in (see Art. XII French Declaration of the Rights of Man, AN 1789).

\section{A Common Misconception About 'the' Public Interest in Archaeology}

There is a common misconception among, not just Germanophone, archaeologists about 'the' public interest in archaeology: that it has been fixed immutably in law that (all) archaeology has to be preserved (ideally completely unchanged in situ) for the study by (primarily) future generations. This not only seems to be confirmed by a cursory reading of the relevant state or national laws themselves (e.g. $\$ 1,8$ and 21 DSchG-BW; $\$ 4$ $(1), 5(1)$ and $11(1,5)$ DMSG), but also by the legal commentaries and relevant case law (e.g. Strobl and Sieche 2010, 49; Bazil et al. 2015, 16, 423 ) and international treaties like the Lausanne Charter or the Valletta Convention (ICOMOS 1990, 1; Art. 1 (1) CoE 1992). The interest in preservation is even seen as outweighing the study of archaeology, at least by invasive methods (explicitly so, e.g. Strobl and Sieche 2010, 265-7); sometimes explicitly justified with the argument that 'future generations' of archaeologists will have better, less destructive methods at their disposal than we today (e.g. Brunecker 2008, 16).

Yet, upon more careful examination, this turns out to be an overly simplistic reading: neither in state, national nor international law is 'the public interest' clearly determined to be the 'preservation of (all) archaeology'. Rather, it is the other way around: archaeological heritage is protected by law if there is a public interest in its preservation. And normally, by no means all archaeology is archaeological heritage (or, if using German terminology, a Denkmal), but only such archaeology which is of sufficient (e.g. historical, scientific, artistic, cultural, etc.) significance (or value) that its (unchanged) preservation is actually in the public interest (e.g. $\$ 1$ (1) DMSG; $\$ 2$ (1) DSchG-BW). Nor is it only in the preservation of archaeological heritage that there is a public interest. Rather, many laws and international treaties give equal or even greater weight to a public interest in its scientific study or in its meaningful use (e.g. $\$ 1$ (1) Denkmalschutzgesetz 
Nordrhein-Westfalen (DSchG-NRW; cf. Davydov et al. 2016, 46-7), e.g. for enhancing the collective cultural memory (Art. 1 (1) CoE 1992). Thus, there is not just one public interest being 'the preservation of (all) archaeology', but there are several public interests in archaeology, at least the three listed above, and possibly many more.

In modern democratic states, the 'public interest' is a precondition for any state action (Häfelin and Müller 2002, 113) and thus an instrument used mainly in public law and administration. Its purpose is to enable the state to protect the 'common good' (the-usually many and diverse-individual interests of an undetermined collective; a 'public') from threats (Steiner 2006, 193), e.g. from potential damage caused (to the interests of this collective) if a specific individual (or group thereof) were to fulfil one of their ('private') legal interests. Given that specific individuals party to them can represent their own interests in administrative proceedings, while the 'public' whose interests might be adversely affected cannot, the state must represent the latter. This ensures that individuals cannot reap the benefits of fulfilling their own interests while burdening an undetermined collective of others with the costs or damages caused by their actions. The public interest binds all three branches of the state: the legislature determines in abstract form what it considers to be in the public interest, while the administrative and judicial branch has to implement the public interest as determined in law on a case by case basis (Häfelin and Müller 2002, 116). Thus, if a conflict between two or several legal private and/or public interests exists, the latter two branches have to balance them against each other based on the principle of proportionality (Berka 1999, 156-67).

Where archaeological heritage (but not necessarily all archaeology) is concerned, the legislature has determined by means of heritage protection laws $a$ public interest in the preservation (and possibly the study, meaningful use, etc.) of archaeology which meets the stated legal criteria (of significance) (e.g. $\$ 1$ (1-2) DMSG; \$2 (1) DSchG-BW; \$1 (1) DSchG-NRW). However, there are many other justified private and public interests determined in other law which may equally be 'in' archaeology. For instance, any landowner with archaeology on their property, irrespective of who owns that archaeology, has justified private interests in that archaeology because it affects his property rights. Also, since the right to property is a human and civil right and the protection of such rights is also a public interest (Häfelin and Müller 2002, 117-8), any landowner's right to do with their property as they will is not just their private, but also a protected public interest. Thus, when a conflict between the interests of the landowner and heritage protection arises, the state must balance the private interest of the landowner and a public interest in the protection of his right to property against a public interest in the protection of the archaeological heritage. There are two conflicting public interests in the archaeol- 
ogy in such a case: that in protecting the right of the landowner to do with it as he wishes and that in protecting archaeological heritage.

Indeed, these conflicting interests can even be reversed: if there is a public interest in examining by excavation some archaeology, it can conflict with a private interest of its owner to preserve it unchanged in situ. In such a case, a public interest in studying the archaeology needs to be balanced against a private interest of its owner and a public interest in the protection of his right to property. And indeed, most Germanophone heritage laws contain specific provisions allowing heritage authorities to conduct such research into archaeology even against the wishes of its owner (e.g. $\$ 30$ (1) DMSG; $\$ 10$ (2) DSchG-BW; \& 28 (2) DSchG-NRW).

If we follow this logic, $a$ public interest in the study of archaeology by academic research and $a$ public interest in its preservation can be mutually exclusive. In any such conflict, the prevailing public interest in archaeology must be whatever the interests of any undetermined collective require, whether it is their protection against threats caused by any ('private') interests of any particular individual (or group thereof), or by any other public interests. That public interest in archaeology should be determined in modern democratic societies discursively, with all individuals concerned being given a fair chance to make themselves heard and represent their interests, both where the determination of public interests by the legislature is concerned and in administrative and judicial proceedings.

\section{The Germanophone Heritage Discourse}

Since we archaeologists tend to believe we know what is best for the archaeology, are self-interested because we need it for our research, and have been given authority by the state to represent the public interest, it is important to consider our role in this (public) heritage discourse. Thus, in the following, I will examine the order of the Germanophone public archaeological heritage discourse and the power relationships between 'expert' authorities and ordinary citizens.

While there certainly is such a discourse, the extent to which it can be described as a public discourse is questionable. In Germany at least, following a 'polemic' by Dieter Hoffmann-Axthelm (2000) questioning the role of the state in heritage management for the Green parliamentary party, a wide-ranging debate in public media ensued. Yet, most contributions to it came from professional heritage managers, with only a few from volunteers working for state heritage agencies, and hardly any contributions to that debate concerned themselves with archaeological heritage management (Donath 2000). In Austria, by comparison, not even devastating findings of the Austrian Court of Audit (RH 2017) regarding the performance and 
lack of transparency of the Austrian National Heritage Agency led to any significant published, let alone a truly public, debate about (archaeological) heritage management.

This is not due to a lack of interest among members of the public (Karl et al. 2014, 19; Siegmund et al. 2017, 244). Rather, while there are many charities and individuals with an interest in heritage, by and large, they seem unable to make themselves heard or meaningfully contribute to a public discourse about heritage management or public interests in archaeological heritage (see, for example, Burghart 2015; Baumgartner 2015; cf. Kemper 2017).

In fact, even within the archaeological disciplines, discourse seems mostly subdued and stifled as it is hardly a free and equal discourse according to Habermas' $(1992,249)$ criteria. Even state archaeological heritage managers admit openly to this: 'The lack of a debate of the foundations of archaeological heritage management is due to a general consensus of all participating experts since about two centuries' (Pollak 2011, 227). ${ }^{2}$ This consensus leads to a uniform approach to archaeological heritage management, mainly by means of the instruments of heritage law, across all Germanophone jurisdictions: professional archaeologists believe we have to protect the archaeology ' $\ldots$ by means of the law in the interest of all ... from the grasp of all' (Lüth 2006, 102). ${ }^{3}$

\section{Determining the Public Interest}

In practice, this leads to a system in which all decision-making powers regarding the determination of the public interest rest almost exclusively with state authorities. There are hardly any means for non-professionals, and even most professionals, to be meaningfully incorporated in decisionmaking processes, let alone to influence decisions. Instead, the law is interpreted as containing a general requirement to report all finds of anything which 'could' be archaeology to the authorities (e.g. $\$ 8$ DMSG, $\$ 20$ DSchG-BW), and for all archaeological field research-sometimes even including purely visual, non-invasive searches-to be explicitly permitted by them (e.g. $\$ 11$ DMSG, $\$ 21$ DSchG-BW). Whether there is a public interest in this (potential) archaeology at all, or what this interest might be, in many cases is not even properly considered, nor properly balanced against other stakeholder interests (see, for example, Karl 2019a, 8-27).

The authority to make any decisions regarding what is archaeology, what is archaeological heritage, and what actions affecting either are in the public interest rests preferably with the state archaeologists or depends exclusively on expert opinions (explicitly, e.g. Bazil et al. 2015, 22-3; Strobl and Sieche 2010,73-4). This authority then is used by heritage officials to 
discursively restrict (e.g. Strobl and Sieche 2010, 266-7) even constitutionally protected, unconditional civil liberties like the freedom of research (in Austria, by Art. 17 Staatsgrundgesetz; in Germany by Art 5 (3) Grundgesetz; cf. Berka 1999, 342-7; Jarass and Pieroth 2016, 238-48), even in cases where there is no indication that any public interest in the preservation of any archaeological heritage could be adversely affected by it. At the same time, they explicitly argue that heritage law contains a 'state research privilege' (Strobl and Sieche 2010, 265), ${ }^{4}$ which conveniently, (only) state archaeologists can exercise. Even more conveniently, such 'state research' is argued to be exempt from heritage protection-related permit requirements even if not exempted by law; e.g. with the rather spurious argument that 'it would be nonsensical if the state heritage agency would have to issue formal permits to itself (Strobl and Sieche 2010, 269). ${ }^{5}$

A perfect exemplar of Smith's (2006, 29-34) Authorised Heritage Discourse, dissenting views about what is in the public interest and how it is to be determined are even repressed within the academic discourse, not least by a highly hierarchical order even among professionals (Karl 2010, 120-42), and even more so with non-professionals. Based on the most cursory of analyses, individuals are divided into different groups according to a handful of questionable criteria, and based on this are collectively considered to be good, morally dubious, or evil (Fig. 1). The further to the right the group is shown on Fig. 1 that individuals are assigned to, the less authority is given to their opinions and the less value to their interests; with those of groups on the far right apparently not needing to be considered at all (even where they are fully legally justified).

\section{Euphemisms and Devaluations}

This discourse is also characterised by a highly selective use of euphemisms for our own, and derogatory terms for the activities and interests of others (e.g. developers, metal detectorists, collectors, and art dealers). This selective framing further exposes the inherent power imbalance between different groups affected by, but only partially being able to participate in, this discourse.

For instance, professional archaeological excavations are always referred to with very positive terms, whether as, 'research excavations' ${ }^{6}$, 'rescue excavations', 'emergency recovery", etc., leading to 'preservation by record'; rather than as the 'partially recorded destruction' of the affected archaeology, which would equally be possible and arguably much more accurate. This is especially so given that it is common professional practice to machine-strip at least the topsoil, often unsearched (Karl 2019b, 9-11), and at least occasionally to partially machine-excavate undisturbed strata 


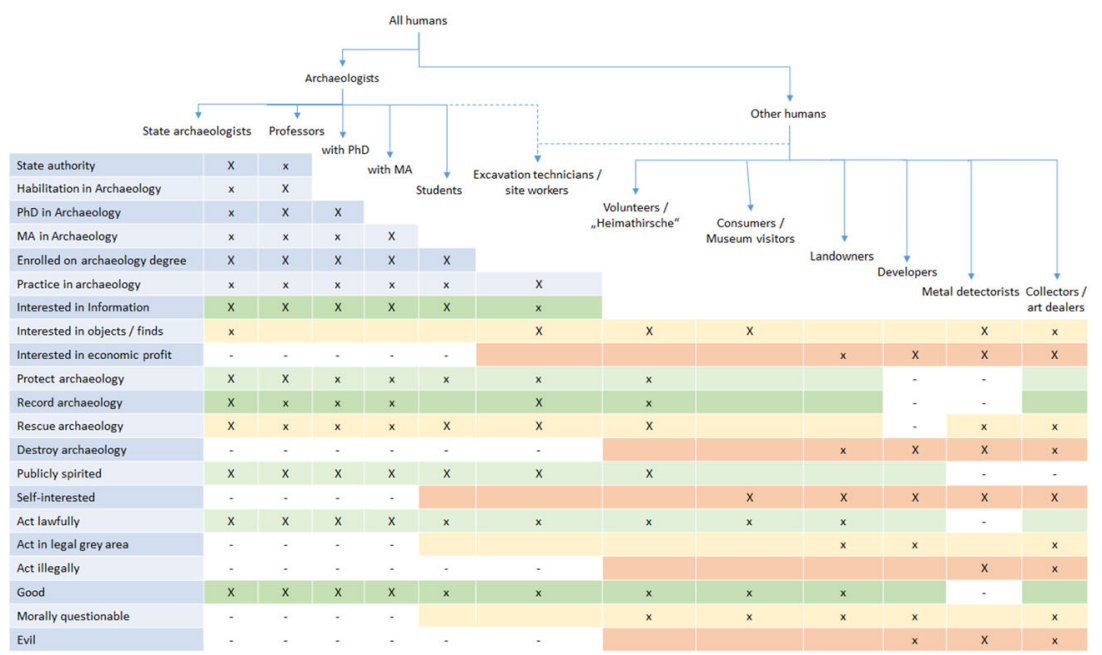

Figure 1. The hierarchical order of authority in the Germanophone archaeological heritage discourse. The further to the left the group an individual belongs to is situated, the higher their authority, with the opinions and interests of all groups classed as partially or exclusively 'evil' being disregarded completely. Assignment of individuals to particular groups is partially based on whether they have professional training, partially on their (assumed) motives for engaging with archaeology, and partially on the (assumed) legality (or illegality) of their actions (adapted from Karl 2016, 4). $X=$ always meets criterion, $x=$ may meet criterion. Moral quality ascribed to criteria: Green $=$ positive, Yellow $=$ neutral, Red $=$ negative.

or apply radical sampling strategies where the excavation of certain types of features or even whole sites is concerned (Siegmund and Scherzler 2014, 172).

In stark contrast to this, intentional finds recovery by non-professionals, especially if 'unauthorised', is almost invariably referred to by negatively loaded terms like 'robbery dig' ${ }^{10}$, 'looting' ${ }^{11}$, etc.; rather than as 'unsystematic finds recovery', which would equally be possible. Indeed, the term 'robbery digger' is frequently indiscriminately used for all metal detectorists without giving any consideration to the actions of any individual so branded. This paints with the same brush those who clandestinely extract archaeology ex situ (e.g. dig up archaeological heritage without a state permit where legally required to have one, without landowner consent, and/or without complying with compulsory finds reporting duties, etc.), and those who engage in archaeological fieldwork with a permit by the relevant heritage agency (i.e. who lawfully exercise their constitutionally guaranteed civil right to conduct research). This is despite the fact that comparatively little discernible damage seems to be done by non-professional finds 
extraction to 'undisturbed' archaeological contexts, and that c. $99 \%$ of finds made by non-professionals seems to be recovered from the topsoil, which would most probably be removed by mechanical digger during professional excavations at the same spot (Karl 2019b, 11-22). Indeed, it is even despite the fact that recording standards attached as conditions to heritage agency permits for non-professional recovery of small finds from the topsoil can require permit holders to record much more information about recovered finds and their contexts than those attached to professional fieldwork permits (compare, for example, the recording standards attached as conditions to metal detecting permits in Hesse, LfDH n.d., with those attached to professional archaeological fieldwork permits, LfDH 2017).

Perhaps even worse than that, many professional archaeologists deploy dehumanising language when referring to non-professionals. Whether it is individuals which pursue entirely justified archaeological research interests of their own lawfully, or whether it is such engaging in clandestine finds extraction, they are literally referred to as animals: 'homeland stags ${ }^{12}$, '(black) sheep'13, etc. (cf. 'lonely wolves' in Norway, Rasmussen 2014, 902; 'nighthawks' in the UK, Oxford Archaeology 2009). Such inappropriate language, especially if, as it is, also applied to citizens engaging in entirely lawful activities to exercise a fundamental human right (see Art. 27 of the Universal Declaration of Human Rights; UN 1948), discursively devalues the justified legal interests of these citizens.

Given that respect for and protection of human dignity is the highest constitutional value of the German Grundgesetz (Jarass \& Pieroth 2016, 41 ), with inviolable and inalienable human rights explicitly defined as the foundation of any human society, peace and justice (Art. 1 (2) Grundgesetz), with the same principle being the foundation of the Austrian state (Berka 1999, 1-3), this framing seems hardly consistent with what should be expected in a free public discourse between equal citizens. Rather than a means to establish what is in the public interest where archaeology is concerned, this discourse seems to be subverted by us 'experts' to undermine the most important public interest of liberal-egalitarian democratic societies: to preserve human dignity.

\section{Experts Rule}

This problem is exacerbated by the fact that 'the public'-or rather, the many different stakeholders who may have justified legal interests in archaeology, and thus also in being heard in determining what the public interests in archaeology are (and how heavily they weigh when balanced 
against other public and private interests) - are also almost completely excluded from the legal discourse about heritage.

Where legislation is concerned, while in democratic countries like Austria and Germany, citizens have the right to vote in elections, political parties rarely publish clear statements about what (changes to) public interests in archaeology they might wish to implement when elected. Thus, even voting rights are mostly meaningless where influencing the public interests in archaeology as determined in legislation is concerned.

Heritage laws are developed and written mostly by the heritage agencies or at least in close consultation with them by the relevant ministry, that is, by heritage bureaucrats. Almost invariably, these either are, or at least draw strongly on the expertise of, heritage professionals. Other stakeholder groups are rarely consulted during the drafting of (changes to) the law, least of all 'ordinary' citizens or interest groups lacking a strong lobby (e.g. 'volunteers', 'consumers', and 'metal detectorists' in Fig. 1). In most of the German states, there is at least a public consultation on the final drafts of laws, though these are hardly advertised widely, and it is questionable whether any submissions by members of the public are seriously considered by the relevant legislature. Speaking from experience of participating in several such consultations, I have yet to see one where any submission by any individual or (non-professional) civil society organisation has led to changes, let alone significant ones, even where a significant percentage or even majority of such submissions argued for the same or very similar changes (also see DGUF 2016, which arrives at the same conclusion). In Austria, where heritage legislation is a responsibility of the federal state, there was not even a public consultation process until September 2017 (Parlament n.d.). In effect, interested citizens simply are not party to the legislative process, at least not in any meaningful way.

Experts on the other hand, especially those in heritage agencies, do have significant powers to influence the legislative process. This is evident when looking at changes to Austrian archaeological heritage law, introduced in the 1999 revision of the DMSG. The particular change in question concerned the eligibility to be issued a field research permit, which until this revision could be granted to everyone (provided they could demonstrate the competence necessary for exercising the freedom of research). In the 1999 revision of the relevant provision of the law, $\$ 11$ (1) DMSG, the possibility to be granted such a permit was restricted to archaeology graduates exclusively. As a justification for this change, the explanatory report to the government draft of the law explains: 'The regulation included in the 1990 revision, that ... archaeological field research permits can also be issued to persons who do not hold an appropriate academic degree was struck off, since it has become out-dated: new models under the direction of fully trained archaeologists (resp. pre- and protohistorians) have since 
successfully been tried and tested.' (RV 1999, 55) ${ }^{14}$. It is self-evident that just one particular interest group-archaeology graduates-benefits from this change, while it is massively detrimental to all other (at least c. $99.85 \%$ of all) Austrian citizens, whose freedom of archaeological field research is entirely removed by this provision.

Putting it bluntly, it is us archaeologists who write archaeological heritage laws, laws which, if at all, are then modified by major lobbies (of developers, large landowners, etc.) with direct access to politicians. Ordinary citizens and civil society, on the other hand, have virtually no chance to influence the legislative process and thus are not heard in the process of determining what the public interests in archaeology are.

\section{Interpreting the Law}

Pretty much the same applies where the interpretation of the law is concerned: the opinions and interests of anyone but 'experts' are virtually never considered.

To again provide an example from Austria, the Bundesdenkmalamt (BDA), the National Heritage Agency, has interpreted the provision of $\$$ 11 (1) DMSG (e.g. in BDA 2016, 6-20) as if it stipulated that all excavations and other 'research in situ with the purpose of discovering or examining' archaeology 'may only be conducted with permission of the BDA' ${ }^{15}$ for at least several decades. It insisted on this regardless of whether any protected archaeological heritage (monuments) or even only (unprotected) archaeological remains were known or suspected to exist on the property in question. It has done so despite the fact that $\$ 1$ (1) DMSG explicitly states that 'The provisions contained in this federal law are applicable to immobile and portable manmade objects ... of historical, artistic or other cultural significance ("monuments"), provided their preservation is in the public interest due to that significance ${ }^{\prime 16}$, and $\$ 1$ (4) DMSG that "The public interest in the preservation in the sense of Abs. 1 (protection) becomes legally effective by force of legal presumption $(\$ 2)$ or by decree $(\$ 2 \mathrm{a})$ or by official letter by the Bundesdenkmalamt $(\$ 3)^{\prime}{ }^{17}$. By any fair interpretation, this must mean that the permit requirement of $\$ 11$ (1) DMSG — which is, after all, a provision of that federal law-can only be applicable if research is conducted to discover or examine protected monuments (in the preservation of which there is a legally effective public interest): after all, a public interest which is not legally effective cannot trigger the applicability of a legal provision, since it has no legal force (it cannot trigger legal action).

Yet, this appears to be considered to be irrelevant by the BDA, despite the fact that I brought and won two cases against it in the Austrian Federal 
Court of Administrative Appeals (BVwG, decisions: 11.9.2017, W183 2168814-1/2E; 19.9.2018, W 195 2197506-1/11E), challenging that very interpretation, and there being Supreme Administrative Court case law directly contradicting the BDA's interpretation (VwGH, decision: 23.2.2017, Ro 2016/09/0008; cf. Karl 2019a, 8-27). Still, the BDA continues to interpret this provision as a general permit requirement for all archaeological fieldwork and reports 'unauthorised' fieldwork on sites (in the preservation of which there is no legally effective public interest) to the prosecuting authorities for alleged violations of the provisions of $\$ 11$ (1) DMSG. If not even directly conflicting Federal Appellate and Supreme Court case law on the very point of law can change its interpretation by a heritage agency, what chances will non-professionals have to exercise their civil right to conduct research on archaeology (in the preservation of which there is no legally effective public interest) unhindered by the state and its officials? None!

\section{Application in the Judicial System}

How this interpretation is applied to non-experts in the judicial system can be demonstrated by an exemplary case from Austria: in 2012, a non-professional metal detectorist conducted a search on land on which no archaeology is known or suspected to exist. This land is near a known ruin of a mediaeval castle, in the preservation of which, however, there is no legally effective public interest either. In his interview with the prosecuting authority, to which he had been reported by the BDA, he claimed to have been searching for meteorites, which are not man-made objects and thus cannot be 'monuments' according to the definition of $\$ 1$ (1) DMSG. He also claimed to have made no finds and not to have dug at all (BH Melk, decision: 23.9.2013, MES2-V-12 10139/5, 2).

His activities had been witnessed by two 'archaeologists', one of whom had reported the case to the BDA. When interviewed by the prosecution, he stated that he and his colleague had been conducting an archaeological land survey (research in situ with the purpose of discovering or examining archaeology) on request of the BDA when spotting two metal detectorists searching in a field, whom they approached, with the defendant in the case identifying himself to them by name. They also had-after the detectorists had left the site-discovered and photographically recorded recently backfilled holes in the area of the mediaeval ruin. It is not mentioned anywhere in the interview summary that they actually observed the metal detectorists having dug any of these (BH Melk, decision: 23.9.2013, MES2-V-12 10139/ $5,2-3)$. It is also noteworthy in this context that the two 'archaeologists' at the time were still students who had not yet completed their first degree 
and who, as far as I could establish, at this time were also not employees of the BDA. Thus, they could not legally have been issued with a $\$ 11$ (1) DMSG permit or been covered by the exemption of fieldwork by the BDA itself of $\$ 11$ (2) DMSG.

The summary of the expert opinion the BDA had submitted to the prosecuting authority in this case after the defendant had been interviewed (BH Melk 23.9.2013, MES2-V-12 10139/5, 3) indicates that it had argued that the claims made by him were not credible. It stated that detectorists would normally search for archaeological finds rather than meteorites, and that mediaeval castle ruins are known to be productive in finds. However, as far as can be determined, it neither provided any evidence that the defendant had actually been searching for monuments, that he had actually dug any holes or made any finds, nor that any monuments in the preservation of which there is a legally effective public interest actually exist on the land he was suspected of or observed metal detecting.

Nonetheless and despite the fact that he had not admitted any wrongdoing, there was no actual evidence that he had committed any wrongful act, and the principle 'innocent until proven guilty' applying in Austria, too, the detectorist was fined for the offence of having breached the permit requirement of $\$ 11$ (1) DMSG. Since he could not prove a negative-something which is obviously impossible-the (entirely prejudicial) 'expert' opinion of the BDA of the 'normal' intentions of metal detectorists prevailed. The two archaeology students, on the other hand, one of whom had actually admitted to having conducted archaeological fieldwork despite not being legally eligible to be granted a $\$ 11$ (1) DMSG permit and not being a BDA employee, were not even reported to the prosecuting authorities by the BDA, nor fined for breaching the very same provision of the law as the detectorist.

It even seems as if the reporting to prosecuting authorities of cases of suspected or evident offences against the DMSG by the BDA is generally highly eclectic and discriminatory. This is not only evident from this particular case, but even more so from the systematic failure by the BDA to enforce the law against professional archaeologists who evidently breached the provisions of $\$ 11$ (1) and (6) DMSG. As is evident from the BDA's own annual finds reports, of the 1674 fieldwork projects the BDA had permitted according to $\$ 11$ (1) DMSG in the years 2013-2015, a total of 89 had not submitted any report by the deadline for submissions to the, respectively, relevant volume of the FÖ (52/2013: 35 reports not received; 53/2014: 31; 54/2015: 23). This deadline is two months after the legal deadline for the submission of such reports to the BDA stipulated in $\$ 11$ (6) DMSG. Non-submission of the compulsory report by the latter deadline is an offence under $\S 37$ (3.7) DMSG, punishable by a fine of up to $€ 5000$. Yet, as far as I could establish, not a single one of these offences by profes- 
sional archaeologists against the DMSG was reported by the BDA to the prosecuting authorities, despite there being proof positive of the offence having been committed in each of these cases in the BDA's own records (Karl 2019b, 25-8).

\section{Wissen ist Macht $^{18}$}

Whether any of this discourse and expert rule is compliant with the principle of equality before the law, enshrined twice in Austrian constitutional law (Art. 7 (1) Bundes-Verfassungsgesetz; Art. 2 Staatsgrundgesetz), seems somewhat questionable, to say the least. Whether any of it is actually in the public interest, especially the public interest determined by a free and open discourse in which citizens have equal opportunities to represent their own interests, as it should be in a liberal-egalitarian democracy, must equally be doubted.

Rather, this short analysis has demonstrated that we, as 'the experts', have immense and mostly unchecked power where the determination of the public interest in archaeology and how it is managed is concerned. Perhaps not in theory, but most certainly in practice, it is primarily (at least some of) us archaeologists who determine the core content, the interpretation, and the execution of archaeological (heritage protection) laws; in Austria and Germany to the extent that it can be irrelevant whether there actually is a public interest in the preservation (or study) of the archaeology concerned, whether it has become legally effective, and whether other justified (or even unconditionally constitutionally guaranteed) legal interests of citizens or other public interests in archaeology are voided by it. Even convictions of ordinary citizens can be secured for alleged breaches of heritage legislation without a sliver of actual proof, while 'good' archaeologists are let off without as much as a slap on the wrist even if the archaeological authorities have proof positive that they committed offences against heritage law. In some regard at least, it appears as if there is one rule for us, and another for all others; as if we archaeologists, and especially state archaeologists, are privileged, while others are discriminated against.

The reason for this lack of discussion and consensus of what public interest really means is a particular order of the discourse about (the public interest in) archaeology and heritage management. This order assigns exclusive authority to 'experts' and even among these, mostly a tiny minority of 'special experts' who hold public office. These 'experts' are virtually the only ones who can make their voices heard in the ('public') discourse about heritage, because their opinions are misconstrued both internally and externally as 'true' and their interests accepted by the state and its other officials as equivalent to the public interest. They also are in an 
extremely privileged position, because due to the structure of the administrative system, they get to determine not just what the public interest in archaeology is, but also the legal instruments, as well as their interpretation and how they are to be applied, with virtually no (effective) checks or balances. In short, 'expert' knowledge equals power.

Since the origins of our discipline and of archaeological heritage management in the 19th century, this power has been and is still being used (or rather abused) to almost completely suppress a truly public discourse of the kind that should be the norm in liberal-egalitarian democracies. Rather than as citizens, anyone who is not part of the 'expert' elite is effectively treated as a subject which is required to listen and obey. Participatory or stakeholder rights, transparency or even only legal certainty may exist in theory, but in practice, archaeologists largely rule as a kind of Plato's philosopher king. As such, we seem to see no need to find out, because we believe to already truly know, what is in the public's best interest; which (just by pure coincidence?) happens to be exactly what is our selfinterest. Thus, we believe we may and indeed must enforce it upon our lesser qualified subjects, even against their will, by any means necessary (Watzlawick 2001, 102-3).

It may of course be purely coincidental that this is exactly the power relationship, and also the power imbalance, characteristic for absolutist monarchies, whose bureaucracies autocratically determined on behalf of the Emperor what was in the public interest and then enforced their will on his subjects. But given that there has been 'a general consensus of all participating experts since about two centuries' (Pollak 2011, 227), it seems more likely it is anything but, especially since it is exactly the power relationship created and maintained by the Authorised Heritage Discourse, whose very function it is to deny the legitimacy of any interests other than those of us 'experts' in anything we have claimed as 'heritage' (Smith 2006, 29-34). At least in Austria and Germany, at least where archaeological heritage is concerned, we (or at least some of us) archaeologists reign absolute, because we have managed to preserve, not so much the archaeology, but a model of public administration that does not serve the actual public interest in archaeology, but primarily our self-interest.

\section{Open Access}

This article is licensed under a Creative Commons Attribution 4.0 International License, which permits use, sharing, adaptation, distribution and reproduction in any medium or format, as long as you give appropriate credit to the original author(s) and the source, provide a link to the Crea- 
tive Commons licence, and indicate if changes were made. The images or other third party material in this article are included in the article's Creative Commons licence, unless indicated otherwise in a credit line to the material. If material is not included in the article's Creative Commons licence and your intended use is not permitted by statutory regulation or exceeds the permitted use, you will need to obtain permission directly from the copyright holder. To view a copy of this licence, visit http://creativeco mmons.org/licenses/by/4.0/.

\section{Notes}

1. e.g. $\$ 1$ (1-2) and 5 (1) Austrian Denkmalschutzgesetz (DMSG); cf. Bazil et al. 2015, 17-21, 48-9; $\$ 2$ (1) and 8 (1) Denkmalschutzgesetz Baden-Württemberg (DSchG-BW); cf. Strobl and Sieche (2010, 71-7, $166-70)$.

2. 'Das weitgehende Fehlen einer Diskussion zu den Grundlagen der archäologischen Denkmalpflege im deutschen Sprachraum beruht auf einem weitgehenden Konsens aller beteiligten Fachleute seit etwa zweihundert Jahren,(Pollak 2011, 227).

3. '... qua Gesetz im Interesse aller ... vor den Zugriffen aller' (Lüth 2006, 102).

4. 'Nachforschungsvorrecht des Landes'(Strobl and Sieche 2010, 265).

5. 'Es wäre unsinnig, wenn das Landesamt für Denkmalpflege sich selbst förmliche Genehmigungen ausstellen müsste'(Strobl and Sieche 2010, 269)

6. 'Forschungsgrabung'.

7. 'Rettungsgrabung'.

8. 'Notbergung'.

9. 'Erhaltung durch Dokumentation'.

10. 'Raubgrabung', with the first part of this term, 'Raub-', normally referring to a crime against moveable property by threatening or committing a violent act in the German language.

11. 'Plünderung', a term normally referring to the illegal appropriation of portable property during war or civil unrest in the German language.

12. 'Heimathirsche'(e.g. Jung 2010).

13. '(schwarze) Schafe'(e.g. Leskovar and Traxler 2011).

14. 'Die durch die Novelle 1990 vorgesehene Regelung, dass ... Grabungsgenehmigungen auch an Personen vergeben werden können, die keine einschlägige abgeschlossene universitäre Ausbildung haben, wurde, da überholt, gestrichen: es haben sich neue Modelle unter Leitung voll ausgebildeter Archäologen (bzw. Ur- und Frühgeschichtler) zwischenzeitig bewährt' (RV 1999, 55). 
15. The law actually stipulates that excavations and'... research in situ with the purpose of discovering or examining portable or immoveable monuments under the surface of the earth or water may only be conducted with permission of the BDA', "... Nachforschungen an Ort und Stelle zum Zwecke der Entdeckung und Untersuchung beweglicher und unbeweglicher Denkmale unter der Erd- bzw. Wasseroberfläche dürfen nur mit Bewilligung des Bundesdenkmalamtes vorgenommen werden...'(\$11 (1) DMSG).

16. 'Die in diesem Bundesgesetz enthaltenen Bestimmungen finden auf von Menschen geschaffene unbewegliche und bewegliche Gegenstände ... von geschichtlicher, künstlerischer oder sonstiger kultureller Bedeutung („Denkmale“) Anwendung, wenn ihre Erhaltung dieser Bedeutung wegen im öffentlichen Interesse gelegen ist'( $\$ 1$ (1) DMSG).

17. 'Das öffentliche Interesse an der Erhaltung im Sinne des Abs. 1 (Unterschutzstellung) wird wirksam kraft gesetzlicher Vermutung (\$2) oder durch Verordnung des Bundesdenkmalamtes (\$ 2a) oder durch Bescheid des Bundesdenkmalamtes (\$ 3)...'(\$1 (4) DMSG).

18. Knowledge is power.

\section{References}

AN.

(1789). Déclaration des Droits de l'Homme et du Citoyen. Paris: Assemblée National. https://www.conseil-constitutionnel.fr/le-bloc-de-constitu tionnalite/declaration-des-droits-de-l-homme-et-du-citoyen-de-1789. Accessed October 31, 2019.

Baumgartner, C.

(2015). Kulturvernichtung im Auftrag der Regierung? Denkma[i]l - Nachrichten der Initiative Denkmalschutz, 21, 6-8.

Bazil, C., Binder-Krieglstein, R., \& Kraft, N.

(2015). Das österreichische Denkmalschutzrecht. Denkmalschutzgesetz und Kulturgüterrecht, Durchführungsvorschriften, Unionsrecht. Kurzkommentar. Wien: Manz.

BDA.

(2016). Richtlinien für archäologische Maßnahmen. 4. Fassung-1. Jänner (2016). Wien: Bundesdenkmalamt.

Berka, W.

(1999). Die Grundrechte: Grundfreiheiten und Menschenrechte in Österreich. Wien, New York: Springer.

Bloch, M.

(1961). Feudal society (Vol. 2). Chicago: University of Chicago Press. 
Brunecker, F.

(2008). Faszination Schatzsuche: Von Ausgräbern und Raubgräbern. In F. Brunecker (Ed.), Raubgräber, Schatzgräber (pp. 14-39). Biberach: Museum Biberach/Theiss.

Burghart, W.

(2015). Editorial. Denkma[i]l - Nachrichten der Initiative Denkmalschutz, 21, 1.

CoE.

(1992). European convention on the protection of the archaeological heritage (revised). CETS No. 143, Valletta: Council of Europe, https://www.coe.int/e $\mathrm{n} /$ web/conventions/full-list/-/conventions/rms/090000168007bd25.

Accessed October 31, 2019.

(2005a). Council of Europe framework convention on the value of Cultural Heritage for Society. CETS No. 199, Faro: Council of Europe, https://www.c oe.int/en/web/conventions/full-list/-/conventions/rms/090000168008374 6 Accessed October 31, 2019.

(2005b). Explanatory Report to the Council of Europe Framework Convention on the Value of Cultural Heritage for Society. Faro: Council of Europe. http s://rm.coe.int/CoERMPublicCommonSearchServices/DisplayDCTM Content?documentId=09000016800d3814. Accessed October 31, 2019.

Davydov, D., Hönes, E.-R., Otten, T., \& Ringbeck, B.

(2016). Denkmalschutzgesetz Nordrhein-Westfalen. Kommentar. 5th ed. Wiesbaden: Kommunal- und Schul-Verlag.

Donath, M. (Ed.).

(2000). Entstaatlichung der Denkmalpflege? Von der Provokation zur Diskussion. Eine Debatte über die Zukunft der Denkmalpflege. Berlin: Vereinigung der Landesdenkmalpfleger in der Bundesrepublik Deutschland.

Elias, N.

(1997). Über den Prozess der Zivilisation. Soziogenetische und psychogenetische Untersuchungen. Frankfurt a.M.: Suhrkamp.

Foucault, M.

(2000). Die Ordnung des Diskurses. 7th pbk.ed., Frankfurt a.M.: Fischer.

Habermas, J.

(1992). The structural transformation of the public sphere. Cambridge: University Press.

Häfelin, U., \& Müller, G.

(2002). Grundriss des Allgemeinen Verwaltungsrechts (4th ed.). Zürich: Schulthess.

Hoffmann-Axthelm, D.

(2000). Kann die Denkmalpflege entstaatlicht werden? Eine Streitschrift. Gutachten für die Bundestagsfraktion von Bündnis 90/Die Grünen. Entwurf. In M. Donath (ed.), Entstaatlichung der Denkmalpflege? Von der Provokation 
zur Diskussion. Eine Debatte über die Zukunft der Denkmalpflege, 9-31. Berlin: Vereinigung der Landesdenkmalpfleger in der Bundesrepublik Deutschland.

ICOMOS.

(1990). Charter for the Protection and Management of the Archaeological Heritage. Lausanne: ICOMOS, http://wp.icahm.icomos.org/wp-content/uploads/20 17/01/1990-Lausanne-Charter-for-Protection-and-Management-of-Archa eological-Heritage.pdf. Accessed September 20, 2019.

Jarass, H.D., \& Pieroth, B.

(2016). Grundgesetz für die Bundesrepublik Deutschland. Kommentar, 14th ed., München: C.H. Beck.

Jung. M.

(2010). „Heimathirsche“. Hobbyarchäologen zwischen Hedonismus und Professionalisierung. Münster: Waxmann.

Kant, I.

(1784). Beantwortung der Frage: Was ist Aufklärung? Berlinische Monatsschrift 4, 481-94, http://www.deutschestextarchiv.de/book/show/kant_aufklaerung_ 1784. Accessed October 1, 2019.

Karl, R.

(2010). Macht und Ohnmacht des positivistischen Denkens. Der Positivismus in der deutschsprachigen Ur- und Frühgeschichte unter besonderer Berücksichtigung des Instituts für Ur- und Frühgeschichte der Universität Wien. Beiträge zur Ur- und Frühgeschichte Mitteleuropas 58, Langenweissbach: Beier \& Beran.

(2016). Obrigkeit und Untertan im denkmalpflegerischen Diskurs. Standesdenken als Barriere für eine Citizen Science? Forum Kritische Archäologie, $5,1-15$.

(2019a). Rechtswidrige Denkmalpflege? Eine (nicht nur österreichische) Realsatire über archäologische NFG-Pflichten; deren gesetzliche Grenzen; und die staatliche Denkmalpflege. Archäologische Denkmalpflege, Sonderband 2, Bangor: https://archdenk.blogspot.co.uk. Accessed October 1, 2019.

(2019b). An empirical examination of archaeological damage caused by unprofessional extraction of archaeology ex situ ('looting'). A case study from Austria. Archäologische Denkmalpflege, 2, 1-34.

Karl, R., Burin, B., Frana, Z., Gufler, V., Hörhan, J., Medek, A., et al.

(2014). Archäologische Interessen der österreichischen Bevölkerung. Bericht und Analyse einer Umfrage, November 2013-Jänner 2014. Bangor Studies in Archaeology, Report No. 8, Bangor/Gwynedd: School of History, Welsh History and Archaeology. 
Kemper, T.

(2017). Das Verbandsklagerecht und die Entwicklung des (Rechts-) Verhältnisses von Denkmalschutzbehörden und Öffentlichkeit. Archäologische Informationen, 40, 43-50.

Leskovar, J., \& Traxler, S.

(2011). Sondengänger und Raubgräber. Versuch einer definitorischen Kategorisieriung. Mit einer Antwort auf Raimund Karl. Fundberichte aus Österreich, 50, 149-155.

LfDH

n.d. Richtlinien zur Dokumentation von Fundstellen. Wiesbaden: Landesamt für Denkmalpflege.

(2017). Richtlinien Archäologie zur Grabungs- und Prospektionsdokumentation für Fachfirmen und Forschungsinstitutionen und zur Behandlung von Grabungsfunden und Proben. Stand 1.8.2017. Wiesbaden: Landesamt für Denkmalpflege.

Lüth, F.

(2006). Einführung in das Thema. Archäologisches Nachrichtenblatt, 11(2), 102106.

Oxford Archaeology.

(2009). Nighthawks \& Nighthawking: Damage to Archaeological Sites in the UK \& Crown Dependencies caused by Illegal Searching \& Removal of Antiquities. Strategic Study, Final Report. Oxford: Oxford Archaeology.

Parlament

n.d. Erweitertes Begutachtungsverfahren. Vienna: Republik Österreich Parlament, https://www.parlament.gv.at/PERK/BET/MESN/. Accessed November 5, 2019.

Pollak, M.

(2011). Zur Theorienbildung der archäologischen Denkmalpflege in Österreich. Österreichische Zeitschrift für Kunst und Denkmalpflege LXV/3, 227-239.

Rasmussen, J. M.

(2014). Securing cultural heritage objects and fencing stolen goods? A case study on museums and metal detecting in Norway. Norwegian Archaeological Review, 7(1), 83-107.

RH.

(2017). Bericht des Rechnungshofes: Bundesdenkmalamt. Reihe Bund 2017/23, Wien: Rechnungshof, http://www.rechnungshof.gv.at/fileadmin/down loads/_jahre/2017/berichte/teilberichte/bund/Bund_2017_23/Bund_2017_ 23_1.pdf. Accessed October 1, 2019.

RV.

(1999). Regierungsvorlage. Bundesgesetz, mit welchem das Bundesgesetz betreffend Beschänkungen in der Verfügung über Gegenstände von geschichtlicher, künstlerischer oder kultureller Bedeutung (Denkmalschutzgesetz - DMSG) 
geändert wird. 1769 der Beilagen zu den Stenographischen Protokollen des Nationalrates XX. GP, http://www.parlament.gv.at/PAKT/VHG/XX/I /I_01769/fname_140694.pdf Accessed August 12, 2017.

Siegmund, F., \& Scherzler, D.

(2014). Archäologie und Baudenkmalpflege in Nordrhein-Westfalen 2014 - ein Jahr nach dem Ringen gegen Mittelkürzungen und für eine bessere gesetzliche Grundlage. Archäologische Informationen, 37, 153-180.

Siegmund, F., Savvidou, K., Berghäuser, S.-E., Backhaus, I. M., Heddier, R. R., Müller, T. A., et al.

(2017). Das Interesse der Bürger in Deutschland an Archäologie und Antike. Archäologische Informationen, 40, 229-248.

Smith, L.

(2006). Uses of heritage. London \& New York: Routledge.

Steiner, U. (Ed.).

(2006). Besonderes Verwaltungsrecht (8th ed.). Heidelberg: C.F. Müller.

Strobl, H., \& Sieche, H.

(2010). Denkmalschutzgesetz für Baden-Württemberg: Kommentar und Vorschriftensammlung. Stuttgart: Kohlhammer.

UN.

(1948). The universal declaration of human Rights. General Assembly resolution 217 A, New York: United Nations, https://www.un.org/en/universal-decl aration-human-rights/[31/10/2019].

Watzlawick, P.

(2001). Vom Schlechten des Guten oder Hekates Lösungen. 8th pbk.ed., München: Piper.

Publisher's Note Springer Nature remains neutral with regard to jurisdictional claims in published maps and institutional affiliations. 